\title{
dsRNA enhances eotaxin-3 production through interleukin-4 receptor upregulation in airway epithelial cells
}

\author{
K. Tsuji, S. Yamamoto, W. Ou, N. Nishi, I. Kobayashi, M. Zaitsu, E. Muro, Y. Sadakane, \\ T. Ichimaru and Y. Hamasaki
}

ABSTRACT: The exacerbation of asthma during viral infections is mainly explained by neutrophils infiltrating into the airways. However, enhanced functions of eosinophils are also observed. The aim of this study was to reveal the mechanism of how eosinophils are activated during and after viral infection of the airways, using a model of viral infection.

A synthetic double-stranded RNA, poly inosinic-cytidyric acid (poly(IC)), was transfected to a human airway epithelial cell line (BEAS-2B) and the primary bronchial epithelial cells, to mimic a viral infection. The production of chemokines from the cells was investigated.

The transfection of poly(IC), alone, marginally affected the eotaxin-3 production of the cells. However, the transfection of poly(IC) prior to interleukin (IL)-4 stimulation enhanced eotaxin-3 production. Poly(IC) transfection increased mRNA and protein expressions of IL-4 receptor (R)a and IL-2R $\gamma$, components of the IL-4R. In BEAS-2B cells, IL-4-mediated phosphorylation of signal transducer and activator of transcription six was enhanced in poly(IC) transfected cells. This was reversed by the addition of anti-IL-4R $\alpha$ antibody, suggesting the role of an increased number of IL4 receptors in enhanced IL-4-induced eotaxin-3 production. Poly(IC)-induced upregulation of IL$\mathbf{4 R} \alpha$ was inhibited by treatment with cycloheximide or dexamethasone.

In conclusion, these results suggest that viral airway infection may enhance interleukin-4induced eotaxin-3 production through upregulation of the interleukin-4 receptor in airway epithelial cells.

KEYWORDS: Airway epithelial cells, double-stranded RNA, eotaxin-3, interleukin-4 receptor

B ronchial epithelial cells were previously considered to function merely as a barrier to the external environment. However, accumulating evidence has revealed that the cells participate in airway inflammation through the production of a wide range of mediators, including chemokines [1]. Eotaxins are a class of these chemokines. Three eotaxins have been demonstrated: eotaxin-1, -2 and -3 , which are also referred to as chemokine ligand (CCL)11, CCL24 and CCL26, respectively [2-4]. These eotaxins show potent chemoattractant activity toward eosinophils and are, thus, believed to play an important role in the pathogenesis of bronchial asthma [5]. The combined stimulation of tumour necrosis factor- $\alpha$ and interleukin (IL)-4 has been observed to induce eotaxin-1 in cultured bronchial epithelial cells [6]. The cells also produce eotaxin-3 when stimulated with IL-4 or IL-13 [7]. A study by BERKMAN et al. [8] demonstrated an increased mRNA expression of eotaxin-3, but not eotaxin-1, in the airway of asthmatic subjects after an allergen challenge. This suggested the important role of eotaxin-3 in late-phase asthmatic response.

The exacerbation of bronchial asthma is often associated with viral airway infections, including rhinovirus (RV) and respiratory syncytial virus (RSV) $[9,10]$. Bronchial epithelial cells have been reported to produce IL-8 and RANTES in response to RV infection [11, 12]. Thus, bronchial epithelial cells play an important role in recruiting neutrophils and T-lymphocytes into the airways during viral infection. Viral associated wheeze has been demonstrated to be characterised by neutrophilic inflammation in both the upper and lower respiratory tracts without eosinophilia [13]. However, there are several pieces of evidence which also demonstrate the involvement of other inflammatory cells, e.g. eosinophils in the airways during viral infection. The increased production of eotaxin- 1 after viral infection has previously been demonstrated [14].

\section{AFFILIATIONS}

Dept of Pediatrics, Saga University School of Medicine, Saga, Japan.

CORRESPONDENCE

S. Yamamoto

Dept of Pediatrics

Saga University School of Medicine 5-1-1 Nabeshima

Saga-City

Saga 849-8501

Japan

Fax: 81952342064

E-mail: yamamot6@cc.saga-u.ac.jp

Received:

January 312005

Accepted after revision:

July 102005

\section{SUPPORT STATEMENT}

This study was funded, in part, by a grant (C2-14570753) from the Ministry of Education, Science, Sports, and Culture of Japan. 


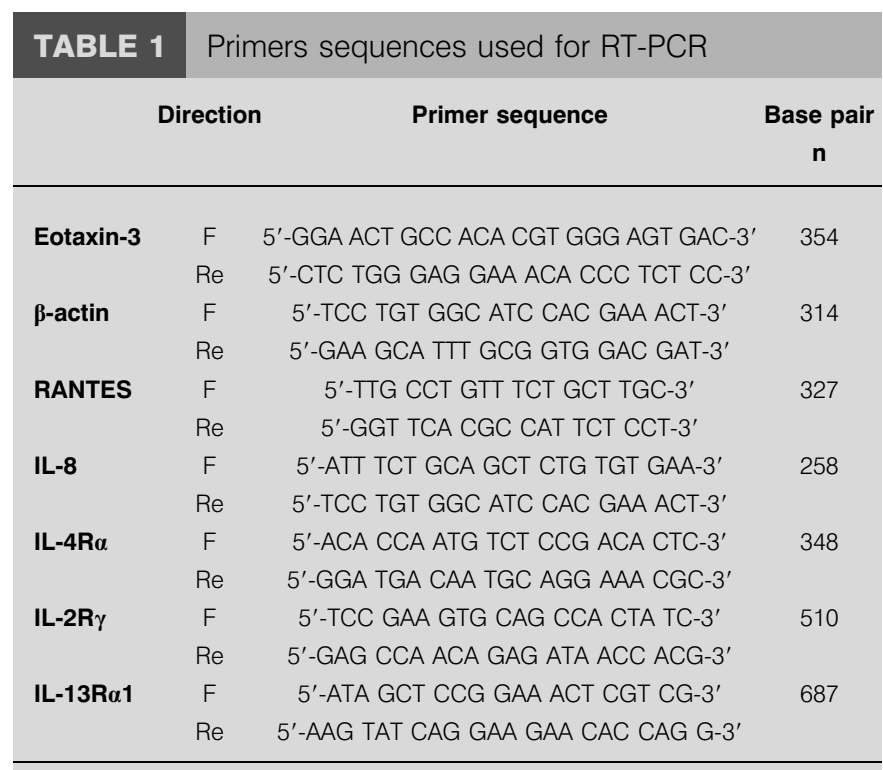

IL: interleukin; R: receptor; F: forward; Re: reverse.

RV infection upregulates eotaxin- 1 and eotaxin-2 expression in the bronchial epithelial cells [15]. Leukotriene $C_{4}$ within upper airway secretions in infants with RSV bronchiolitis is likely to originate from the eosinophils [16]. It has been suggested that eotaxin-3 is specifically involved in late-phase asthmatic response, facts which may not fully explain the exacerbation of asthma during or after viral airway infection. Currently, no information is available on whether eotaxin-3 is upregulated or not during viral infection. Thus, it was hypothesised by the current authors that viral airway infection may increase the eotaxin-3 production of the bronchial epithelial cells, and possibly result in the exacerbation of bronchial asthma in ongoing asthmatic patients.

As a direct result of this hypothesis the effects of doublestranded (ds) RNA on IL-4-induced eotaxin-3 production in cultured human bronchial epithelial cells, including primary cells, was investigated in vitro. The current work, presented in this paper, investigates the possibility that viral airway infections may trigger subsequent allergen-induced airway eosinophilia, in which the upregulation of the IL-4 receptor (IL$4 \mathrm{R})$ by dsRNA plays an important role in the production of eotaxin-3 in airway epithelial cells.

\section{MATERIALS AND METHODS \\ Cells}

The human bronchial epithelial cell line BEAS-2B, was obtained from the American Type Culture Collection (Manassas, VA, USA). Primary cultured normal human bronchial epithelial (NHBE) cells were obtained from Clonetics (Walkersville, MD, USA). Both cells were cultured as previously described [17].

\section{Transfection of dsRNA to the cells}

BEAS-2B and NHBE cells $\left(4 \times 10^{5} \cdot\right.$ well $\left.^{-1}\right)$ were seeded onto sixwell plates $24 \mathrm{~h}$ before transfection. Transfection was carried out using Effectene reagent (QIAGEN, Valencia, CA, USA) according to the manufacturer's instruction. In brief, graded doses of poly inosinic-cytidyric acid (poly(IC); Sigma-Aldrich, St. Louis, MO, USA), a synthetic dsRNA, prepared in $1 \mu \mathrm{L}$ of water were mixed into the reagent and Dulbecco's Modified Eagles Medium. For the control, $100 \mathrm{ng} \cdot \mathrm{well}^{-1}$ of poly deoxyinosinic-deoxycytidyric acid (dIdC; Sigma-Aldrich), a synthetic dsDNA, or $100 \mathrm{ng} \cdot \mathrm{well}^{-1}$ of poly inosinic acid (poly(I); Sigma-Aldrich), a synthetic single-stranded RNA, was used. Cells were incubated at $37^{\circ} \mathrm{C}$ for 24,48 or $72 \mathrm{~h}$ depending on the experiment. After $24 \mathrm{~h}$ of transfection, the transfection reagent was removed by washing the cells with PBS.

\section{Stimulation of the cells}

To induce eotaxin-3 production, cells were stimulated with $50 \mathrm{ng} \cdot \mathrm{mL}^{-1}$ of either IL-4 or IL-13 (Peprotec, London, UK) for $24 \mathrm{~h}$. At the time of transfection, $20 \mu \mathrm{g} \cdot \mathrm{mL}^{-1}$ of cycloheximide (CHX; Sigma-Aldrich) or varying concentrations of dexamethasone (DEX; Sigma-Aldrich) were added to the culture medium. CHX or DEX was removed $24 \mathrm{~h}$ after transfection. To antagonise the action of IL-4R, cells were pre-treated with $20 \mu \mathrm{g} \cdot \mathrm{mL}^{-1}$ of mouse antihuman IL-4R $\alpha$ (Immunotech, Marseille, France) for $15 \mathrm{~min}$, and then stimulated with IL-4. The antibody used was a blocking antibody [18]. Mouse antiimmunoglobulin $\mathrm{G}_{1}$ was used as control.

\section{RT-PCR}

Total RNA was extracted from the cells as previously described [19]. RT-PCR was performed by the conventional method. Sequences of the primers are shown in table 1. PCR settings were as follows for eotaxin-3, $\beta$-actin, IL- $4 R \alpha$, IL$2 \mathrm{R} \gamma$ and IL-13R $\alpha 1$ : first denaturing at $94^{\circ} \mathrm{C}$ for $2 \mathrm{~min}$, then denaturing at $94^{\circ} \mathrm{C}$ for $30 \mathrm{~s}$, annealing at $58^{\circ} \mathrm{C}$ for $30 \mathrm{~s}$, extending at $72^{\circ} \mathrm{C}$ for $30 \mathrm{~s}$, and finally extension at $72^{\circ} \mathrm{C}$ for $2 \mathrm{~min}$. RANTES and IL-8 were annealed at $56^{\circ} \mathrm{C}$ and $50^{\circ} \mathrm{C}$, respectively. For eotaxin-3, 28 cycles of amplification were performed for semiquantitative comparison because the amount of PCR products reached a plateau after 32 cycles (data not shown). For RANTES, IL-8, $\beta$-actin, IL-4R $\alpha$, IL-2R $\gamma$ and IL-13R $\alpha 1,32,32,22,36,38$ and 30 cycles were performed, respectively. The PCR cycles were determined by densitometrical analyses, as previously described [20].

\section{Measurement of protein release in culture medium}

RANTES, IL-8 and eotaxin-3 released into culture medium were measured by ELISA (BioSource, Camarillo, CA, USA, for RANTES and IL-8; R\&D systems, Minneapolis, MN, USA, for eotaxin-3). The minimum detectable doses of RANTES, IL-8 and eotaxin-3 were $3.0 \mathrm{pg} \cdot \mathrm{mL}^{-1}, 5.0 \mathrm{pg} \cdot \mathrm{mL}^{-1}$ and $2.3 \mathrm{pg} \cdot \mathrm{mL}^{-1}$, respectively.

\section{Flow cytometry}

Flow cytometry analyses for the detection of IL- $4 \mathrm{R} \alpha$ and IL-2R $\gamma$ was performed as previously described [20].

\section{Immunoblotting}

Total cellular protein was prepared $24 \mathrm{~h}$ post transfection, as previously described [20]. Immunoblotting for signal transducer and activator of transcription (STAT) 6 and phosphorylated STAT6 was carried out using anti-STAT6 (\#sc-621; Santa Cruz Biotechnology Inc., Santa Cruz, CA, USA) and anti-p-STAT6 (\#sc11762-R; Santa Cruz), respectively, as previously described [20]. 

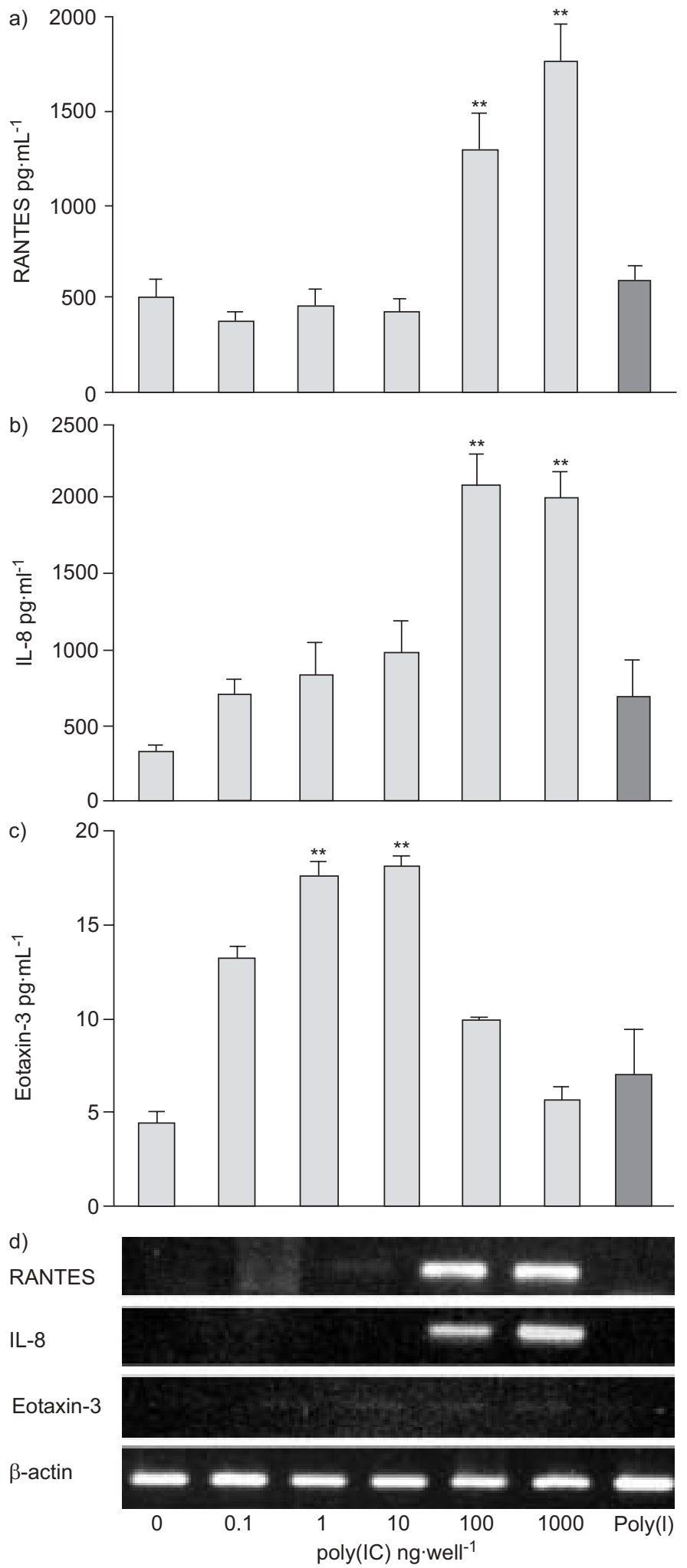

FIGURE 1. BEAS-2B cells were transfected with increasing doses of poly inosiniccytidyric acid (poly (IC); 1 ) or $100 \mathrm{ng} \cdot$ well $^{-1}$ of poly inosinic acid (poly(l); $\square$ ) and incubated for $24 \mathrm{~h}$. The concentrations of a) RANTES, b) interleukin (IL)-8 and c) eotaxin-3 released into the culture mediumwere determined by ELISA. Results shownaremeans \pm SD ofvalues from three separate experiments. ${ }^{* *}: p<0.01$ compares the value in poly $(I)$ transfected cells. d) RANTES, IL-8 and eotaxin-3 mRNA expressions were investigated by RT-PCR.

\section{Statistical analysis}

Data are presented as means \pm SD. The significance of the differences was evaluated by ANOVA, and multiple pairwise comparisons were carried out with the Fischer test in the analysis of protein productions of RANTES, IL-8 and eotaxin-3, and in the analysis of mean fluorescence intensity values in flow cytometry experiments. In the experiments investigating IL-4R $\alpha$ mRNA expression, data were analysed by ANOVA on ranks. A p-value of $<0.05$ was considered statistically significant.

\section{RESULTS}

\section{Effects of poly (IC) on the productions of chemokines}

The effects of poly(IC) on the productions of chemokines from BEAS-2B cells were initially investigated. Poly(IC), but not poly(I), induced RANTES and IL-8 production, as previously described (fig. 1a and b) [21, 22]. A small, yet significant increase in eotaxin-3 production was observed when transfected with $1 \mathrm{ng} \cdot$ well $^{-1}$ or $10 \mathrm{ng} \cdot \mathrm{well}^{-1}$ of poly(IC) (fig. 1c). Dose-dependent enhancement of the mRNA expressions of RANTES and IL-8 was observed, although no apparent induction of eotaxin-3 mRNA expression was detected when amplified to 28 PCR cycles (fig. 1d; gel shown is representative of results from three experiments). Eotaxin-3 mRNA was detected when amplified to 32 PCR cycles. Although the abundance of exotaxin-3 mRNA in poly(IC) transfected cells $\left(10 \mathrm{ng} \cdot\right.$ well $\left.^{-1}\right)$ was greater than that observed in nontransfected cells, the difference was not statistically significant $(p=0.07$; data not shown).

\section{Transfection of poly(IC) enhanced IL-4-induced eotaxin-3 production}

Stimulation with IL-4 or IL-13 induces eotaxin-3 production in BEAS-2B cells $[7,17]$. The effects of poly(IC) transfection on IL-4or IL-13-induced eotaxin-3 production were also investigated. BEAS-2B cells were transfected with increasing doses of poly(IC), IL-4 $\left(50 \mathrm{ng} \cdot \mathrm{mL}^{-1}\right)$ stimulation was started simultaneously and incubation was for $24 \mathrm{~h}$. No significant enhanced IL-4-induced eotaxin-3 production was observed (fig. 2a, white column). However, $48 \mathrm{~h}$ post-incubation with poly(IC) transfection, prior to IL-4 stimulation $\left(50 \mathrm{ng} \cdot \mathrm{mL}^{-1}\right.$ for $24 \mathrm{~h}$ ), allowed significant enhanced eotaxin-3 production in a dose-dependent manner (fig. $2 \mathrm{a}$, grey column). Figure $2 \mathrm{~b}$ shows the effects of $100 \mathrm{ng} \cdot$ well $^{-1}$ of poly(IC) transfection on IL-4- or IL-13-induced eotaxin-3 production. Cells were incubated for $48 \mathrm{~h}$, then stimulated with or without $50 \mathrm{ng} \cdot \mathrm{mL}^{-1}$ of either IL-13 or -14 for $24 \mathrm{~h}$. Small, yet significant enhanced IL-4-induced eotaxin-3 production was observed in the cells transfected with poly(I) when compared with those in the cells without transfection. The IL-4-induced eotaxin-3 production was dramatically enhanced in poly(IC) transfected cells. IL-13-induced eotaxin-3 production was also significantly increased in poly(IC) transfected cells; however, the increase was smaller than observed in IL-4-induced production (a 3.3-fold increase in IL-4-induced production versus a 1.2-fold increase in IL-13-induced production). The effect of poly(I) and poly(IC) transfection on IL-4-induced eotaxin-3 production in NHBE cells was also investigated (fig. 2c). The NHBE cells were stimulated with or without $50 \mathrm{ng} \cdot \mathrm{mL}^{-1}$ of IL-4, 2 days after transfection. Cells were then incubated for an additional $24 \mathrm{~h}$. No eotaxin-3 was detected in the cells transfected with either poly(I) or poly(IC) if the cells were not stimulated with IL-4 (data not shown). IL-4 induced eotaxin-3 

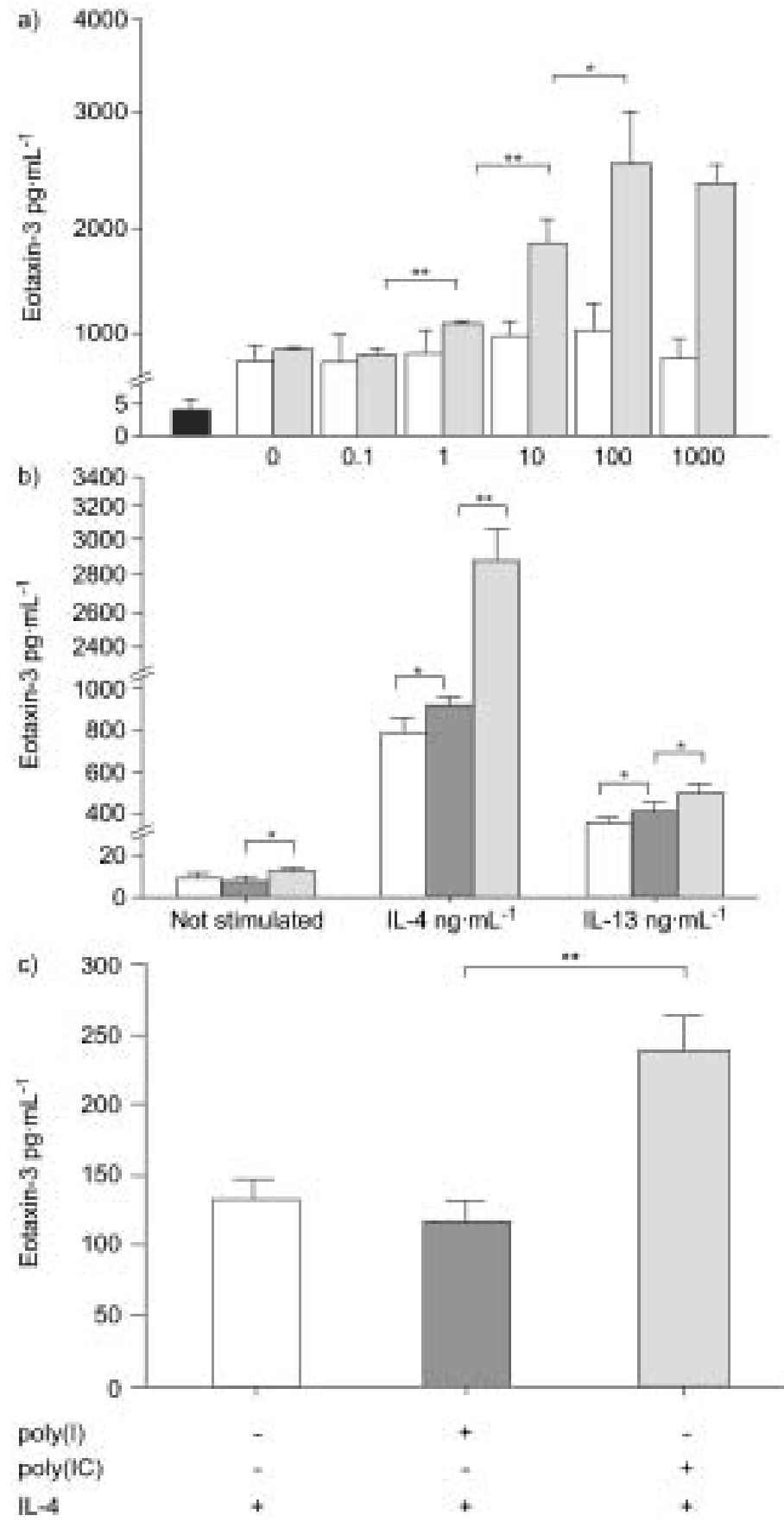

FIGURE 2. a) Effects of poly inosinic-cytidyric acid (poly(IC)) transfection on interleukin (IL)-4-induced eotaxin-3 production. BEAS-2B cells were incubated as indicated. $\mathbf{~ : ~ c e l l s ~ i n c u b a t e d ~ w i t h o u t ~ a n y ~ s t i m u l a t i o n ; ~} \square$ : cells were transfected with varying doses of poly $(\mathrm{IC})$ at the time of stimulation; 1 : cells were incubated for $48 \mathrm{~h}$ after transfection with varying doses of poly(IC). Results shown are means \pm SD of values from three separate experiments. b) BEAS-2B cells with no transfection ( $\square$ ), poly inosinic acid (poly(l)) transfection (100 ng.well ${ }^{-1}$; $\left.\mathbf{D}\right)$, or poly(IC) transfection (100 ng.well ${ }^{-1} ; \quad$ ). Results shown are means \pm SD of values from four separate experiments. C) IL-4-induced eotaxin-3 production in normal human bronchial epithelial (NHBE) cells that were nontransfected $(\square)$ or were transfected with

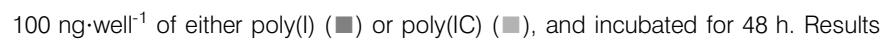
shown are means $\pm S D$ of values from triplicate samples. ${ }^{*}: p<0.05^{* *}: p<0.01$. In all cases, the amount of eotaxin-3 released in the culture medium was determined by ELISA. Methods are provided in greater detail in the main text. production in NHBE cells, as previously described [18]. IL-4induced eotaxin-3 production was significantly higher in poly(IC) transfected cells. In contrast, transfection of poly(I) had no significant effect (fig. 2c).

\section{Poly(IC) enhanced expression of IL-4R complex}

Receptor regulation is one of the most important mechanisms for determining the functions of the ligands, including cytokines. Therefore, the effect of dsRNA on the expression of components of IL- $4 \mathrm{R}$ complexes was investigated. It was observed that the transfection of poly(IC) upregulated IL-4R $\alpha$ mRNA expression, in a dose-dependent manner (fig. 3a). mRNA expression of IL-2R $\gamma$ (not observed before transfection) was induced by transfection of poly(IC) (fig. 3a). However, the transfection of poly(IC) had no apparent effect on IL-13R $\alpha 1$ mRNA expression (fig. 3a). IL- $4 \mathrm{R} \alpha$ and IL-2R $\gamma$ protein expressions at the surface of BEAS-2B cells were further investigated by flow cytometry. Transfection of poly(IC), followed by a 2day incubation period was found to enhance both IL-4R $\alpha$ and IL-2R $\gamma$ protein expressions at the cell surface when compared with those in the cells transfected with poly(I) (figs. $3 b$ and c). Table 2 shows dose-dependent induction of IL-4R $\alpha$ and IL-2R $\gamma$ protein expressions in BEAS-2B cells. Although transfection with poly(I) or poly(dIdC) also induced the increase in IL-4R $\alpha$ protein expressions, the current authors postulated that it was the effect of the transfection reagent because the transfection reagent itself induced a significant increase in IL- $4 \mathrm{R} \alpha$ protein expression. A time-dependent increase in IL- $4 \mathrm{R} \alpha$ expression at the cell surface was also observed (fig. 3d).

A significant upregulation of protein expression of both IL-4R $\alpha$ and IL-2R $\gamma$ at the cell surface by the transfection of poly(IC) was also observed in NHBE cells. The histograms in figures $3 e$ and $f$ show that NHBE cells include at least two cell populations. IL- $4 \mathrm{R} \alpha$ and IL-2R $\gamma$ proteins were upregulated in both these populations by transfection with poly(IC). Upregulation of IL-4R $\alpha$ and IL-2R $\gamma$ mRNA expression was also observed (data not shown).

\section{Cycloheximide inhibited poly(IC)-induced enhancement of IL-4R $\alpha$}

The effect of CHX, an inhibitor of protein synthesis, on IL-4R protein expression at the cell surface in BEAS-2B cells was investigated. When the cells were cultured with $\mathrm{CHX}$, the constitutive expression of IL- $4 \mathrm{R} \alpha$ at the cell surface was significantly inhibited. Poly(IC) transfection-induced IL- $4 \mathrm{R} \alpha$ protein expression was also inhibited by $\mathrm{CHX}$ to a similar degree (fig. 4). These results indicate the role of de novo protein synthesis in IL- $4 \mathrm{R} \alpha$ production by the transfection of poly(IC).

\section{Transfection of poly(IC) induced increased IL-4-mediated cellular signal}

To investigate whether increased expression of IL-4R results in increased IL-4-mediated signal, the effect of poly(IC) transfection on IL-4-induced activation of STAT6 in BEAS-2B cells was investigated. Both IL-4- and IL-13-induced phosphorylation of STAT6 were enhanced in poly(IC) transfected cells when compared with those in nontransfected cells (figures $5 a$ and b). The addition of anti-IL-4R $\alpha$ antibody inhibited IL-4-induced phosphorylation of STAT6 in poly(IC) transfected cells as well as in poly(I) transfected cells (fig. 5c). It was also observed that 
a)

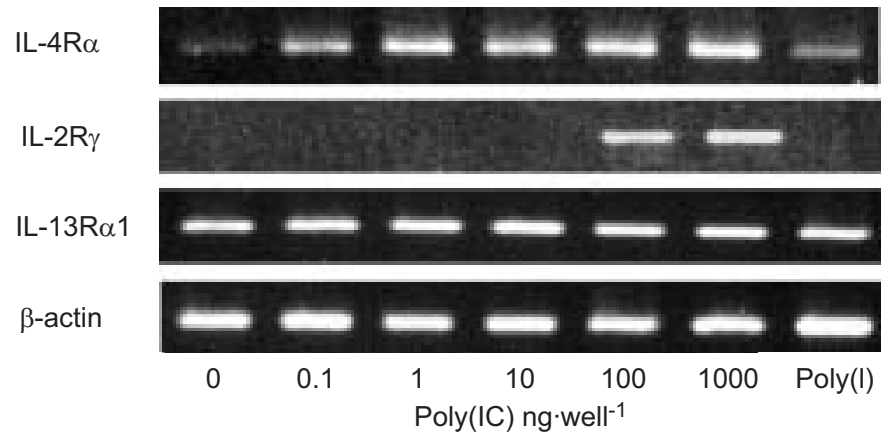

c)

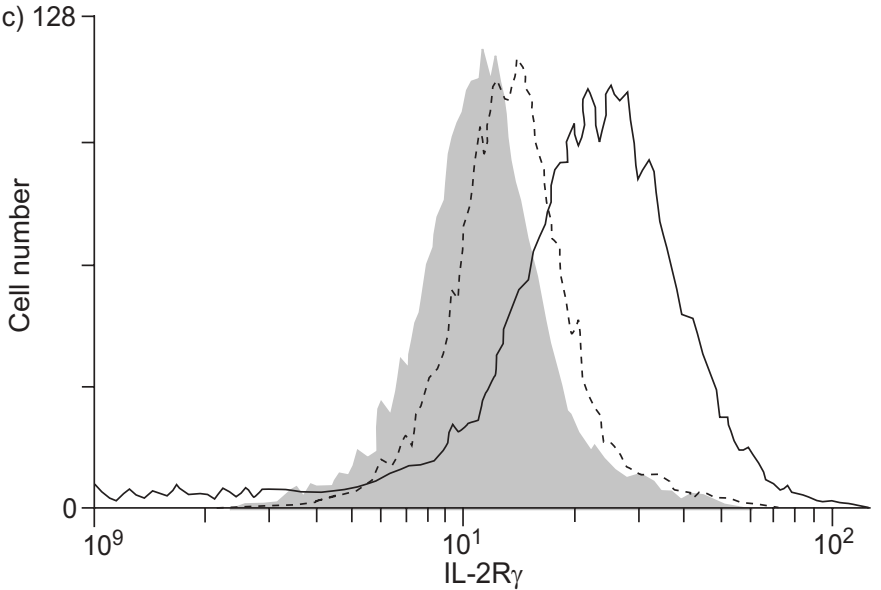

e) 120

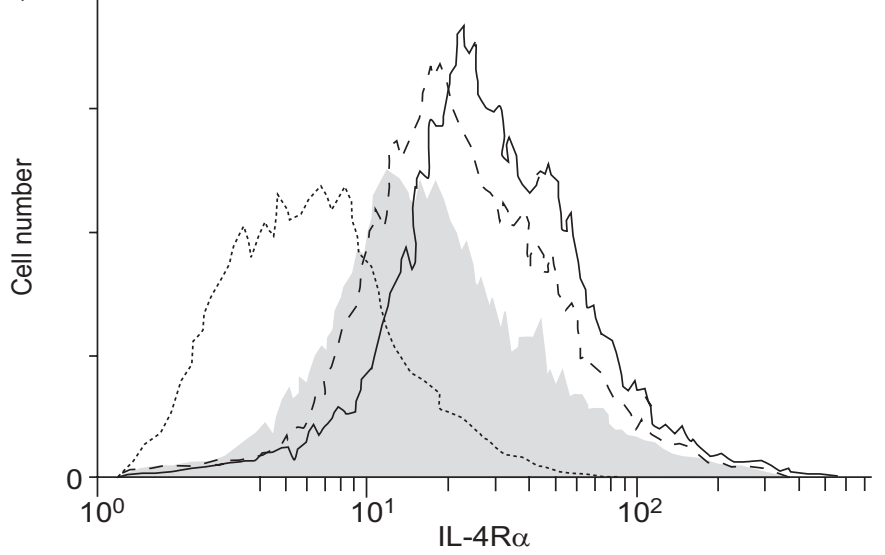

b) 128

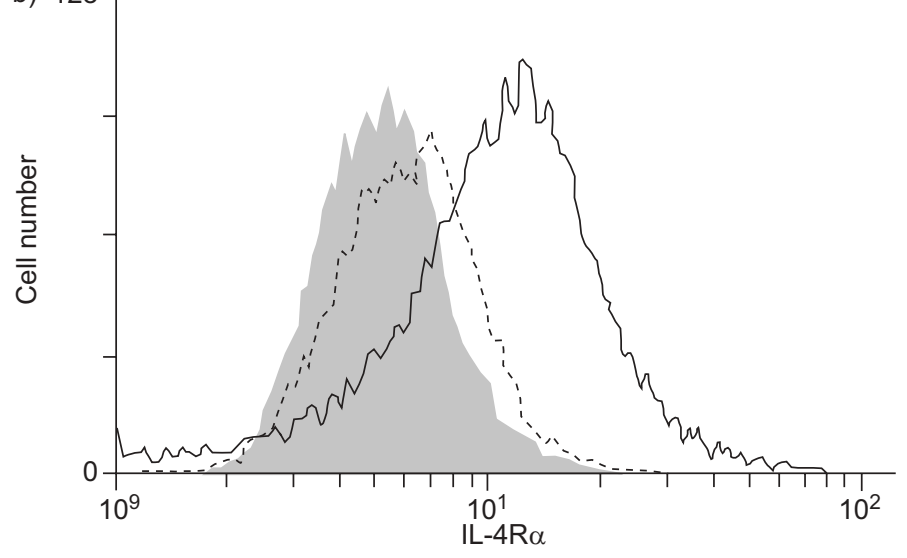

d) 100

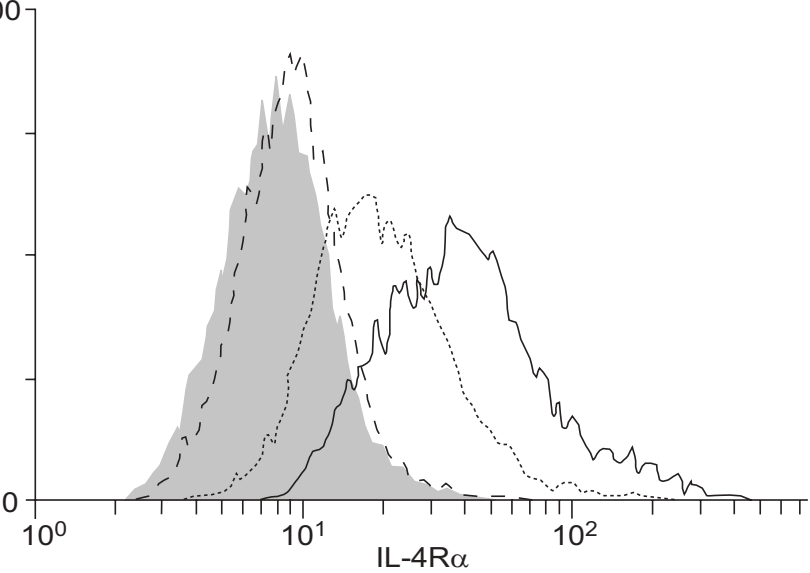

f)

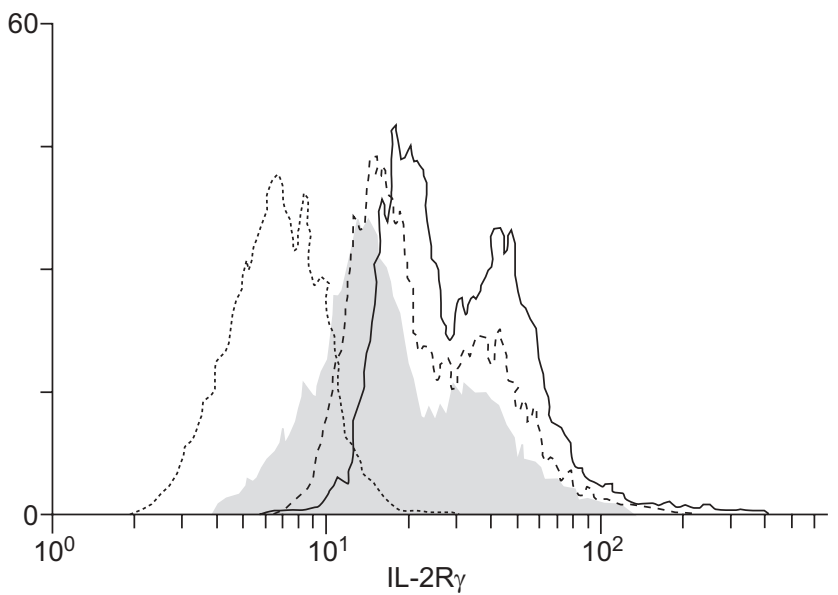

FIGURE 3. a) Effects of poly inosinic-cytidyric acid (poly(IC)) transfection on the mRNA expression of components of interleukin (IL)-4 receptor (R). BEAS-2B cells were transfected with transfection reagent alone, varying doses of poly $(\mathrm{IC})$ or $100 \mathrm{ng} \cdot$ well $^{-1}$ of poly inosinic acid (poly $(\mathrm{I})$ ). The results presented are from one of three experiments which produced similar results. b) IL-4R $\alpha$ and c) IL-2R $\gamma$ expressions at the cell surface in BEAS-2B cells investigated by flow cytometry analysis using mouse anti-human IL-4R $\alpha$ or rat anti-human IL-2R $\gamma$, respectively. Cells were incubated for $48 \mathrm{~h}$ after transfection of either poly(l) (….....) or poly(IC) (-). $\square$ cells not transfected. d) Time kinetics of IL-4R $\alpha$ protein expression. After transfection with $100 \mathrm{ng} \cdot$ well $^{-1}$ of poly(IC), BEAS-2B cells were incubated for $24(---), 48(\cdots \cdots \cdots .$.$) and 72 \mathrm{~h} \mathrm{(-).} \mathrm{e)} \mathrm{IL-4R} \alpha$ and f) IL-2R $\gamma$ expression at the cell surface in normal human bronchial epithelial (NHBE) cells. NHBE cells were incubated for $48 \mathrm{~h}$ after transfection of either poly(l) or

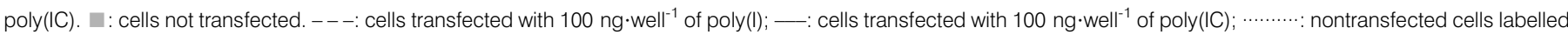
with isotype-matched mouse immunoglobulin (Ig)G (e) or isotype-matched rat $\mathrm{IgG}(\mathrm{f})$. The results presented are from one of two experiments which produced similar results.

anti-IL-4R $\alpha$ completely inhibited IL-4-induced eotaxin-3 production in poly(IC) transfected cells (data not shown). These results suggest that IL-4-induced eotaxin-3 production was totally IL-4R dependent, and that poly(IC) increased the number of IL-4R at the cell surface, thus enhancing the IL-4mediated signal in BEAS-2B cells. 


\begin{tabular}{|c|c|c|c|}
\hline TABLE 2 & \multicolumn{3}{|c|}{$\begin{array}{l}\text { Effect of transfection on interleukin (IL)-4- } \\
\text { receptor (R) } \alpha \text { and IL-2R } \gamma \text { expression at the cell } \\
\text { surface in BEAS-2B cells }\end{array}$} \\
\hline \multirow{2}{*}{\multicolumn{2}{|c|}{ Transfection }} & \multicolumn{2}{|c|}{ Mean fluorescence intensity } \\
\hline & & IL-4R $\alpha$ & IL-2R $\gamma$ \\
\hline \multicolumn{2}{|l|}{ None } & $3.21 \pm 0.20^{\#}$ & $8.01 \pm 0.19^{\#}$ \\
\hline \multicolumn{2}{|l|}{ None } & $4.79 \pm 0.20^{\circ}$ & $14.80 \pm 0.11^{+}$ \\
\hline \multicolumn{2}{|c|}{ Effectene reagent } & $6.34 \pm 0.11^{\S}$ & $14.47 \pm 0.09$ \\
\hline \multicolumn{2}{|c|}{ Poly(l) $100 \mathrm{ng} \cdot$ well $^{-1}$} & $6.35 \pm 0.24^{\S}$ & $14.56 \pm 0.22$ \\
\hline \multicolumn{2}{|c|}{ Poly(dldC) $100 \mathrm{ng} \cdot$ well $^{-1}$} & $6.21 \pm 0.64^{\S}$ & $13.89 \pm 0.46$ \\
\hline \multicolumn{2}{|c|}{ Poly(IC) $1 \mathrm{ng} \cdot$ well $^{-1}$} & $7.03 \pm 0.19^{5, f}$ & $17.45 \pm 0.15^{\S, f}$ \\
\hline \multicolumn{2}{|c|}{ Poly(IC) $10 \mathrm{ng} \cdot$ well $^{-1}$} & $9.42 \pm 0.15^{\S, f}$ & $19.88 \pm 0.14^{\S, f}$ \\
\hline \multicolumn{2}{|c|}{ Poly(IC) $100 \mathrm{ng} \cdot$ well $^{-1}$} & $11.20 \pm 0.23^{\S, f}$ & $24.47 \pm 0.48^{\S, f}$ \\
\hline
\end{tabular}

Data are presented as mean \pm SD from three sets of data. Poly(l): poly inosinicacid; Poly(dldC): poly deoxyinosinic-deoxycytidyric acid; Poly(IC): poly inosinic-

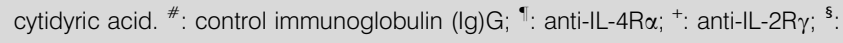
$\mathrm{p}<0.01$ compares the value in nontransfected cells labelled with anti-IL-4R $\alpha$ or anti-IL-2R $\gamma ;{ }^{f}: \mathrm{p}<0.01$ compares the value in poly $(\mathrm{I})$ transfected cells.

\section{Effects of glucocorticoid on poly(IC) induced IL-4R $\alpha$ mRNA expression}

The effects of DEX on the poly(IC)-induced increase of IL-4R $\alpha$ mRNA expression in BEAS-2B cells was investigated. An attenuation of poly(IC)-induced IL-4R $\alpha$ mRNA expression by DEX was observed (figs 6a and b). Flow cytometry analysis, which was performed $48 \mathrm{~h}$ after transfection, showed significant attenuation of poly(IC)-induced IL- $4 \mathrm{R} \alpha$ expression by DEX in a dose-dependent manner (table 3). However, DEX had no effect on the constitutive or poly(I)-induced expression of IL-4R $\alpha$ (table 3). Figure 6c shows the effect of DEX plus poly(IC) on IL-4-induced eotaxin-3 production. In spite of the removal of DEX by washing the cells $24 \mathrm{~h}$ before IL-4 stimulation, DEX treatment attenuated IL-4-induced eotaxin-3 production, both in the cells transfected with poly(I) and in the cells transfected with poly(IC). However, there was no significant difference in eotaxin-3 production between the cells treated with DEX plus poly(I) and the cells treated with DEX plus poly(IC). These results suggest that DEX treatment attenuated poly(IC)-induced IL-4R expression, thus causing the attenuation of IL-4-induced eotaxin-3 production.

\section{DISCUSSION}

There has been increasing interest in the relationship between bronchial asthma and various viral infections, particularly RV and RSV $[10,23]$. These viruses are often associated with the exacerbation of asthma, both in children and in adults [24-26]. RV RNA or transfection of synthetic dsRNA into an airway epithelium has been shown to induce the production of several chemokines, including IL-8 and RANTES, which contribute to the recruitment of neutrophils and activated lymphocytes into the airways [21, 27]. The current study also confirmed the induction of these chemokines by a synthetic dsRNA, poly(IC), in the bronchial epithelial cell line BEAS-2B. Thus, chemokines such as IL-8 and RANTES secreted from the airway epithelium are believed to play an important role in the exacerbation of bronchial asthma.

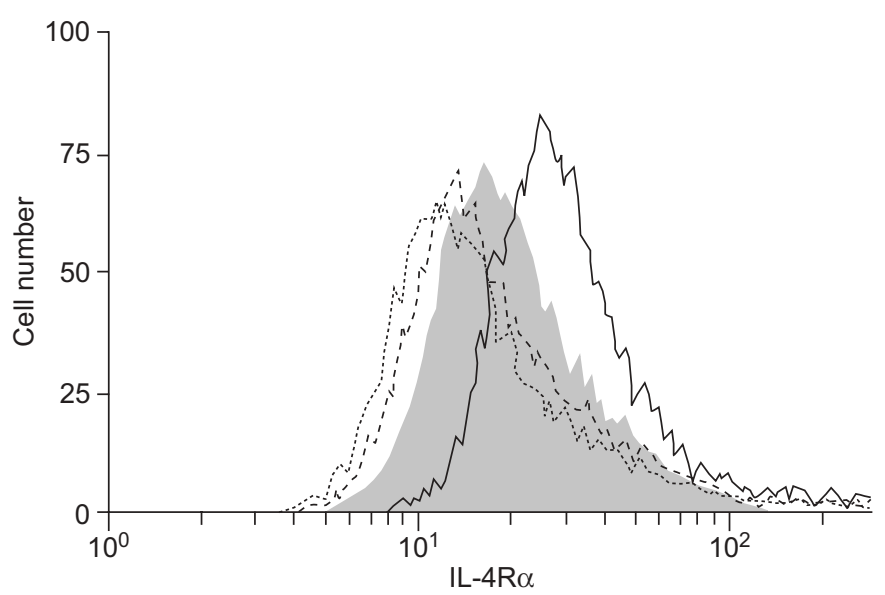

FIGURE 4. Effect of cycloheximide $(\mathrm{CHX})$ on poly inosinic-cytidyric acid (poly $(\mathrm{IC})$ )-induced interleukin (IL)-4 receptor(R) $\alpha$ expression at the cell surface in BEAS-2B. At the time of transfection of poly $(\mathrm{IC}), 20 \mu \mathrm{g} \cdot \mathrm{mL}^{-1}$ of $\mathrm{CHX}$ was added $\left(100 \mathrm{ng} \cdot\right.$ well $\left.^{-1}\right)$. After $48 \mathrm{~h}$ of culture, those cells were subjected to fluorescenceactivated cell sorter analysis. $\square$ : constitutive IL-4R $\alpha$ expression; - - IL-4R $\alpha$ expression in the cells transfected with poly $(\mathrm{IC})$; - - -: cells cultured with $\mathrm{CHX}$ after transfection of poly $(\mathrm{IC}) ; \cdots \cdots \cdots . .$. : cells cultured with $\mathrm{CHX}$ without transfection. The results presented are from one of two experiments which produced similar results.

In the current study, the question was postulated whether dsRNA treatment could induce eotaxin-3 production in bronchial epithelial cells. Eotaxins-1 and -2 were demonstrated to be upregulated in viral airway infection [15]. In BEAS-2B cells, a small amount of eotaxin-3 was induced by the transfection of poly(IC). However, eotaxin-3 was not induced in NHBE cells. Although it is still obscure, the viral infection itself might not have a potent effect on eotaxin-3 production in airway epithelial cells.

The current authors raised the question of whether an airway viral infection might enhance subsequent allergic response. Allergen challenge performed after RV inoculation showed a significantly greater increase in the nasal output of eosinophil peroxidase when compared with that performed before inoculation [28]. In the present study, dsRNA transfection prior to IL-4 stimulation enhanced eotaxin-3 production in both BEAS-2B and NHBE cells. Recently, it has been demonstrated that pre-treatment with interferon (IFN)- $\gamma$ enhanced IL4 -induced eotaxin-3 production, though costimulation with IFN- $\gamma$ and IL-4 suppressed eotaxin-3 production in BEAS-2B cells [20]. Since IFN- $\gamma$ is abundantly produced in a virusinfected airway, the current authors speculated that viral airway infection might sensitise the airway epithelial cells and enhance allergen-induced response, which might result in airway eosinophilia [20]. These combined observations suggest that viral infections of the airway might trigger subsequent allergen-induced airway eosinophilia in ongoing asthmatic patients.

Airway epithelial cells express two types of IL-4 receptors, type 1 and type 2 IL-4Rs [17, 20, 29]. To the current authors' knowledge, this is the first study to report that the transfection of dsRNA enhances the expression of IL- $4 \mathrm{R} \alpha$ and IL-2R $\gamma$, components of type $1 \mathrm{IL}-4 \mathrm{R}$, in airway epithelial cells. IL-4R $\alpha$ 


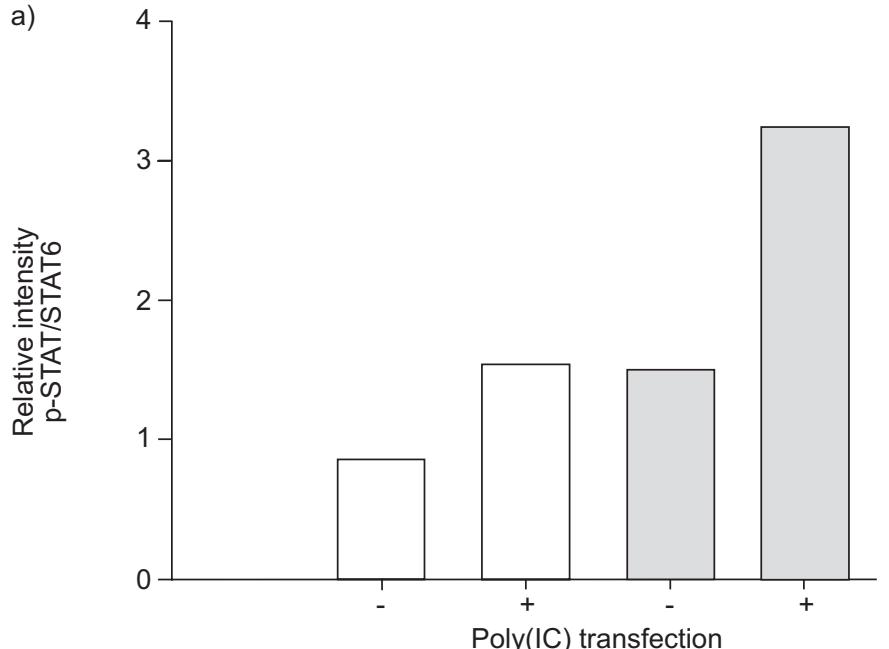

b)

p-STAT6

STAT6

Poly (IC) transfection

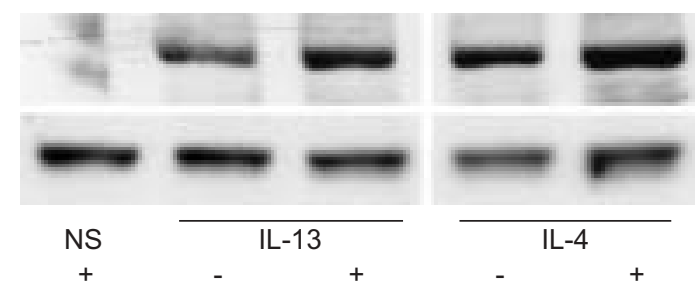

c)

p-STAT6

STAT6

Anti-IL-4R $\alpha$

$\mathrm{IL}-4$

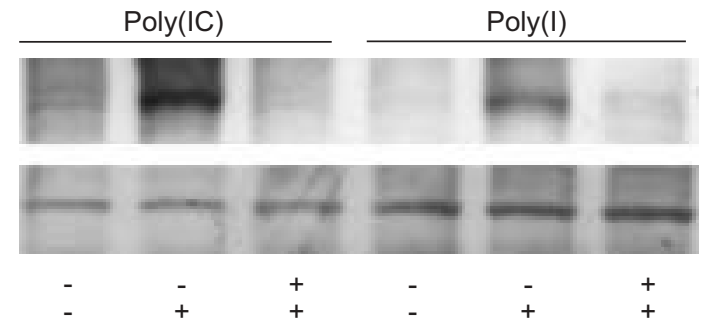

FIGURE 5. a and b) Effects of poly inosinic-cytidyric acid (poly(IC)) transfection on interleukin (IL)-4- or IL-13-induced signal transducer and activator of transcription (STAT)6 activation in BEAS-2B cells. Cells were transfected with transfection reagent alone or with poly(IC) $\left(100 \mathrm{ng} \cdot\right.$ well $\left.^{-1}\right)$, followed by a 48 -h incubation. The cells were then incubated with or without $50 \mathrm{ng} \cdot \mathrm{mL}^{-1}$ of either IL-13 or IL-4, for $30 \mathrm{~min}$. Cell lysate samples were analysed by immunoblotting for STAT6 and p-STAT6, as described in the Materials and Methods section. The result presented is one from two experiments which produced similar results. C) BEAS-2B cells were transfected with $100 \mathrm{ng} \cdot \mathrm{mL}^{-1}$ of either poly $(\mathrm{IC})$ or poly inosinic acid (poly (I)), and incubated for $48 \mathrm{~h}$. Those cells were treated with $20 \mu \mathrm{g} \cdot \mathrm{mL}^{-1}$ of anti-IL$4 \mathrm{R} \alpha$ for $15 \mathrm{~min}$ before stimulation with $50 \mathrm{ng} \cdot \mathrm{mL}^{-1}$ of IL-4 for $30 \mathrm{~min}$. Cell lysate samples were subjected to immunoblotting analysis. The result presented is one from two experiments which produced similar results.

protein has been demonstrated to be synthesised de novo. The results indicate that the enhanced IL-4-induced eotaxin-3 production in poly(IC) transfected cells was due to the upregulation of IL- $4 \mathrm{R}$ expression at the cell surface. The results that poly(IC) enhanced IL-4R-mediated p-STAT6 generation, and that anti-IL-4R antibody inhibited p-STAT6 generation in the poly(IC) transfected cells as well as in poly(I) transfected cells, also support the increased number of IL-4R expression at the cell surface. a)
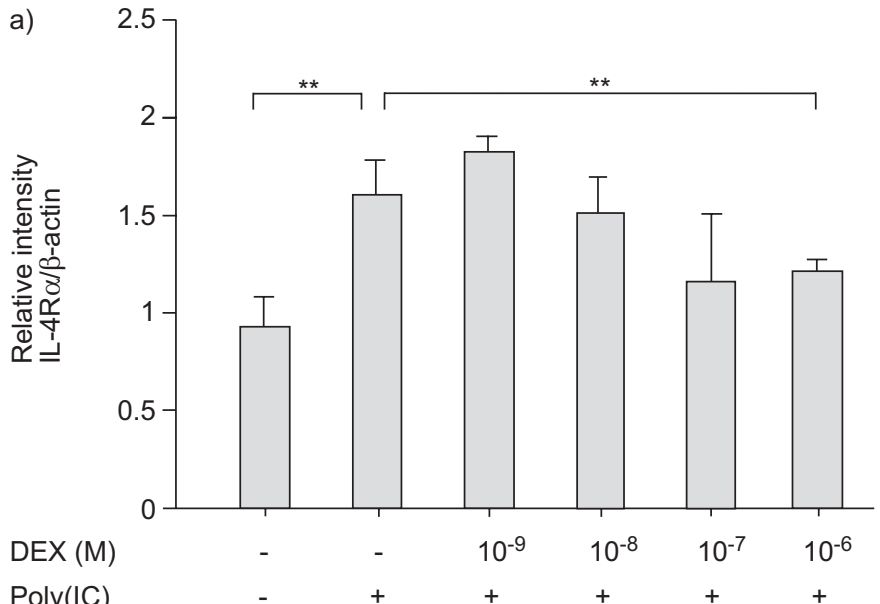

Poly (IC)

b)

IL-4R $\alpha$

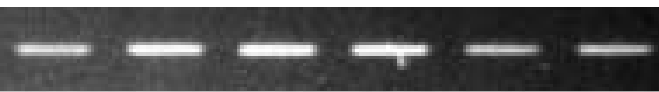

$\beta$-actin

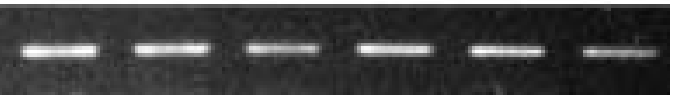

$\operatorname{DEX}(\mathrm{M})$

Poly (IC)

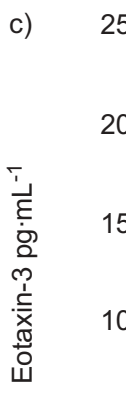

2500
2000
1500
1000
500

Poly (I)

Poly (IC)

DEX

IL-4

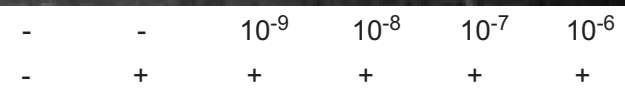

FIGURE 6. a) Effect of dexamethasone (DEX) on poly inosinic-cytidyric acid (poly(IC))-induced interleukin (IL)-4 receptor (R) $\alpha$ mRNA expression in BEAS-2B cells. Varying doses of DEX were added at the time of transfection of poly $(\mathrm{IC})$ $\left(100 \mathrm{ng} \cdot\right.$ well $\left.^{-1}\right)$, and incubated for $24 \mathrm{~h}$. Cells were then subjected to RT-PCR analysis. IL-4R $\alpha$ mRNA expression is expressed as a ratio of $\beta$-actin mRNA expression. Results shown are means \pm SD of values from three separate experiments. b) An ethidium bromide-stained agarose gel shown as a representative of results obtained from three experiments. c) BEAS-2B cells transfected with either $100 \mathrm{ng} \cdot$ well $^{-1}$ of poly inosinic acid or poly(IC) with or without DEX $\left(10^{-6} \mathrm{M}\right)$ were incubated for $24 \mathrm{~h}$, then the cells were washed with PBS. The cells were stimulated $48 \mathrm{~h}$ after transfection with IL-4 $\left(50 \mathrm{ng} \cdot \mathrm{mL}^{-1}\right)$ for $24 \mathrm{~h}$. The amount of eotaxin-3 released into the culture medium was determined by ELISA. Results shown are means $\pm S D$ of values from triplicate samples. ${ }^{*}: p<0.05,{ }^{*}$ : $p<0.01$

The current study demonstrates that the transfection of poly(IC)-induced IL-4R $\alpha$ expression of both mRNA and protein levels was attenuated by DEX. This is the first study 


\begin{tabular}{|c|c|c|c|}
\hline TABLE 3 & \multicolumn{3}{|c|}{$\begin{array}{l}\text { Effect of dexamethasone (DEX) on poly inosinic- } \\
\text { cytidyric acid (poly }(\mathrm{IC}) \text { )-induced interleukin (IL)- } 4 \\
\text { receptor }(\mathrm{R}) \alpha \text { expression at the cell surface of } \\
\text { BEAS-2B cells }\end{array}$} \\
\hline \multirow{2}{*}{\multicolumn{2}{|c|}{ Transfection agent }} & DEX M & Mean fluorescence intensity \\
\hline & & & IL-4Ro \\
\hline \multirow{6}{*}{\multicolumn{2}{|c|}{ Poly(IC) $100 \mathrm{ng} \cdot$ well $^{-1}$}} & 0 & $11.03 \pm 0.24$ \\
\hline & & $10^{-10}$ & $11.07 \pm 0.28$ \\
\hline & & $10^{-9}$ & $10.69 \pm 0.39$ \\
\hline & & $10^{-8}$ & $10.12 \pm 0.42^{\star}$ \\
\hline & & $10^{-7}$ & $7.73 \pm 0.21^{\star *}$ \\
\hline & & $10^{-6}$ & $6.80 \pm 0.18^{\star \star}$ \\
\hline \multirow{2}{*}{\multicolumn{2}{|c|}{ Poly(I) $100 \mathrm{ng} \cdot$ well $^{-1}$}} & 0 & $6.97 \pm 0.48$ \\
\hline & & $10^{-6}$ & $7.10 \pm 0.15$ \\
\hline \multirow[t]{2}{*}{ None } & & 0 & $5.56 \pm 0.33$ \\
\hline & & $10^{-6}$ & $6.03 \pm 0.42$ \\
\hline
\end{tabular}

Data are presented as mean \pm SD from three sets of data. Poly (I): poly inosinic acid. *: $p<0.05 ;{ }^{*}: p<0.01$ compares the value in the cells transfected with poly $(I C)$ without $D E X$ treatment.

that demonstrates the regulation of IL- $4 \mathrm{R} \alpha$ expression by glucocorticoid in airway epithelial cells, although DEX was demonstrated to inhibit IL-4-induced IL-4R $\alpha$ upregulation by translational or post-translational mechanisms in isolated $\mathrm{T}$ and B-lymphocytes [30]. Since the constitutive expression of IL- $4 \mathrm{R} \alpha$ protein was observed not to be affected by DEX, DEX may interfere with transcription factors induced only by dsRNA, and not with those required for constitutive IL-4R gene expression. IL-4-induced eotaxin-3 production was attenuated by DEX treatment even in the cells transfected with poly(I). This may be inconsistent with the current observation that the constitutive expression of IL- $4 \mathrm{R} \alpha$ protein was not affected by DEX. Since DEX itself strongly inhibits IL4-induced eotaxin-3 production [17], the effect of DEX may still have remained at the time of IL-4 stimulation in this experiment. These results suggest that topical glucocorticoid therapy may influence the course of allergic and inflammatory processes during viral infection by downregulating the expression of IL- $4 \mathrm{R} \alpha$ and the IL-4R-mediated production of chemokines, including eotaxin-3, of the airway epithelial cells.

It has been demonstrated that dsRNA interacts with at least two independent cellular systems, in which dsRNA-dependent protein kinase (PKR) and $2^{\prime}-5^{\prime}$-linked oligoadenylate synthase are involved $[22,31]$. The activation of nuclear factor (NF)- $\mathrm{B}$ and mitogen-activated protein kinase (MAPK) pathways, including p38 MAPK and c-Jun N-terminal kinase, has been demonstrated to be involved in dsRNA-dependent cellular signalling [20, 32]. In airway epithelial cells, the activation of PKR, NF- $\mathrm{KB}$ and the p38 MAPK pathway was demonstrated by incubation with poly(IC) or transfection of viral RNA [21, 22]. In BEAS-2B cells, it was recently observed that inhibitors of the MAP and ERK (extracellular signal-regulated kinase) kinase (MEK)1/2 MAPK pathway, in addition to inhibitors of the NF- $\mathrm{B}$ and p38 MAPK pathway, inhibited poly(IC)induced IL-4R $\alpha$ gene expression (unpublished observation).
Several pathways, including MEK1/2 MAPK, may be involved in signal transduction pathways leading to IL-4R $\alpha$ gene expression in airway epithelial cells.

In summary, the current study demonstrates that the transfection of poly inosinic-cytidyric acid enhanced interleukin-4induced eotaxin-3 production in airway epithelial cells, although poly inosinic-cytidyric acid itself showed only marginal effects on eotaxin-3 production. The upregulation of type 1 interleukin- 4 receptor was involved in the mechanism of increasing eotaxin-3 production. Topical steroid therapy might decrease virus-induced interleukin-4 receptor expression, and, thus, be effective for asthmatic patients. These results might explain the relationship between viral airway infections and the exacerbation of bronchial asthma. Since the current study is only a model of viral infection, which may not perfectly reflect in vivo interactions, further study is needed to confirm the results by using real viruses or an in vivo model of a viral infection.

\section{ACKNOWLEDGEMENTS}

The authors would like to thank M. Ozeki for her technical assistance.

\section{REFERENCES}

1 Romagnani S. Cytokines and chemoattractants in allergic inflammation. Mol Immunol 2002; 38: 881-885.

2 Garcia-Zepeda EA, Rothenberg ME, Ownbey RT, Celestin J, Leder $\mathrm{P}$, Luster AD. Human eotaxin is a specific chemoattractant for eosinophil cells and provides a new mechanism to explain tissue eosinophilia. Nat Med 1996; 2: 449-456.

3 Forssmann U, Uguccioni M, Loetscher P, et al. A novel CC chemokine that is selective for the chemokine receptor CCR3, and acts like eotaxin on human eosinophil and basophile leukocytes. J Exp Med 1997; 185: 2171-2176.

4 Kitaura M, Suzuki N, Imai T, et al. Molecular cloning of a novel human CC chemokine (eotaxin-3) that is a functional ligand of CC chemokine receptor 3. J Biol Chem 1999; 274: 27975-27980.

5 Rojas-Ramos E, Avalos AF, Perez-Fernandez L, CuevasSchacht F, Valencia-Maqueda E, Teran LE. Role of the chemokines RANTES, monocyte chemotactic proteins-3 and -4 , and eotaxins- 1 and -2 in childhood asthma. Eur Respir J 2003; 22: 310-316.

6 Matsukura S, Stellato C, Georas SN, et al. Interleukin-13 upregulates eotaxin expression in airway epithelial cells by a STAT6-dependent mechanism. Am J Respir Cell Mol Biol 2001; 24: 755-761.

7 Komiya A, Nagase H, Yamada H, et al. Concerted expression of eotaxin-1, eotaxin-2, and eotaxin-3 in human bronchial epithelial cells. Cellular Immunol 2003; 225: 91-100.

8 Berkman N, Ohnona S, Chung FK, Breuer R. Eotaxin-3 but not eotaxin gene expression is upregulated in asthmatics 24 hours after allergen challenge. Am J Respir Cell Mol Biol 2001; 24: 682-687.

9 Johnston SL, Pattemore PK, Sanderson G, et al. Community study of role of viral infections in exacerbations of asthma in 9-11 year old children. BMJ 1995; 310: $1225-1229$. 
10 Gern JE. Rhinovirus respiratory infections and asthma. Am J Med 2002; 112: Suppl. 6a, 19S-27S.

11 Subauste MC, Jacoby DB, Richard SM, Proud D. Infection of a human respiratory epithelial cell line with rhinovirus: induction of cytokine release and modulation of susceptibility to infection by cytokine exposure. J Clin Invest 1995; 96: 549-557.

12 Schroth MK, Grimm E, Frindt $\mathrm{P}$, et al. Rhinovirus replication causes RANTES production in primary bronchial epithelial cells. Am J Respir Cell Mol Biol 1999; 20: 1220-1228.

13 Mackean MC, Hewitt C, Lambert PC, Myint S, Silverman M. An adult model of exclusive viral wheeze: inflammation in the upper and lower respiratory tracts. Clin Exp Allergy 2003; 33: 912-920.

14 Weinberg JB, Lutzke ML, Efstathiou S, Kunkel SL, Rochford R. Elevated chemokine responses are maintained in lungs after clearance of viral infection. J Virol 2002; 76: 10518-10523.

15 Papadopoulos NG, Papi A, Meyer J, et al. Rhinovirus infection up-regulates eotaxin and eotaxin-2 expression in bronchial epithelial cells. Clin Exp Allergy 2001; 31: 1060-1066.

16 Dimova-Yaneva D, Russell D, Main M, Brooker RJ, Helms PJ. Eosinophil activation and cysteinyl leukotriene production in infants with respiratory syncytial virus bronchiolitis. Clin Exp Allergy 2004; 34: 555-558.

17 Kobayashi I, Yamamoto S, Nishi N, et al. Regulatory mechanisms of Th2 cytokine-induced eotaxin-3 production in bronchial epithelial cells: possible role of IL-4 receptor and nuclear factor-kappaB. Ann Allergy Asthma Immunol 2004; 93: 390-397.

18 Zurawski SM, Chomarat $\mathrm{P}$, Djossou $\mathrm{O}$, et al. The primary binding subunit of the human interleukin-4 receptor is also a component of the interleukin-13 receptor. J Biol Chem 1995; 270: 13869-13878.

19 Yamamoto S, Hamasaki Y, Ishii E, Ichimaru T, Miyazaki S. Unbalanced production of interleukin-5 and interleukin-2 in children with atopic dermatitis. Ann Allergy Asthma Immunol 1997; 78: 517-523.

20 Yamamoto S, Kobayashi I, Tsuji K, et al. Upregulation of IL-4R by IFN- $\gamma$; enhanced IL-4-induced eotaxin-3 production in airway epithelium. Am J Respir Cell Mol Biol 2004; 31: 456-462.
21 Gern JE, French DA, Grindle KA, Brockman-Schneider RA, Konno S, Busse WW. Double-stranded RNA induces the synthesis of specific chemokines by bronchial epithelial cells. Am J Respir Cell Mol Biol 2003; 28: 731-737.

22 Uetani K, Arroliga ME, Erzurum SC. Double-stranded RNA dependence of nitric oxide synthase 2 expression in human bronchial epithelial cell BET-1 and BEAS-2B. Am J Respir Cell Mol Biol 2001; 24: 720-726.

23 Lemanske JRF. Viruses and asthma: inception, exacerbation, and possible prevention. J Pediatr 2003; 142: Suppl. 2, S3-S8.

24 Rylander E, Eriksson M, Pershagen G, Nordvall L, Ehrnst A, Ziegler T. Wheezing bronchitis in children. Incidence, viral infections, and other risk factors in a defined population. Pediatr Allergy Immunol 1996; 7: 6-11.

25 Nicholson KG, Kent J, Hammersley V, Cancio E. Risk factors for lower respiratory complications of rhinovirus infections in elderly people living in the community: prospective cohort study. BMJ 1996; 313: 1119-1123.

26 Heymann PW, Carper HT, Murphy DD, et al. Viral infections in relation to age, atopy, and season of admission among children hospitalized for wheezing. J Allergy Clin Immunol 2004; 114: 239-247.

27 De Smedt A, Vanderlinden E, Demanet C, Waele DM, Goossens A, Noppen M. Characterization of pleural inflammation occurring after primary spontaneous pneumothorax. Eur Respir J 2004; 23: 896-900.

28 Greiff L, Venge P, Andersson M, et al. Effects of rhinovirusinduced common colds on granulocyte activity in allergic rhinitis. J Infect 2002; 45: 227-232.

29 Gessner A, Rollinghoff M. Biologic functions and signaling of the interleukin-4 receptor complexes. Immunobiology 1999; 201: 285-307.

30 Mozo L, Gayo A, Suarez A, Rivas D, Zamorano J, Gutierrez C. Gulucocorticoids inhibit IL-4 and mitogen-induced IL-4R alpha chain expression by different posttranscriptional mechanisms. J Allergy Clin Immunol 1998; 102: 968-976.

31 Samuel CE. Antiviral actions of interferons. Clin Microbiol Reviews 2001; 14: 778-809.

32 Iordanov MS, Paranjape JM, Zhou A, et al. Activation of p38 mitogen-activated protein kinase and c-Jun NH2-terminal kinase by double stranded-RNA and encephalomyocarditis virus: involvement of RNase $\mathrm{L}$, protein kinase $\mathrm{R}$, and alternative pathways. Mol Cell Biol 2000; 20: 617-627. 